\title{
Interleukin-1 $\beta$ Causes Anxiety by Interacting with the Endocannabinoid System
}

\author{
Silvia Rossi, ${ }^{1,2}$ Lucia Sacchetti, ${ }^{3}$ Francesco Napolitano, ${ }^{4,5}$ Valentina De Chiara, ${ }^{1,2}$ Caterina Motta, ${ }^{1,2}$ Valeria Studer, ${ }^{1,2}$ \\ Alessandra Musella, ${ }^{1,2}$ Francesca Barbieri, ${ }^{1,2}$ Monica Bari, ${ }^{6}$ Giorgio Bernardi, ${ }^{1,2}$ Mauro Maccarrone, ${ }^{2,7}$ \\ Alessandro Usiello, ${ }^{4,5,8}$ and Diego Centonze ${ }^{1,2}$ \\ ${ }^{1}$ Clinica Neurologica, Dipartimento di Neuroscienze, Università Tor Vergata, Via Montpellier 1, 00133 Rome, Italy, ${ }^{2}$ Fondazione Santa Lucia/Centro \\ Europeo per la Ricerca sul Cervello (CERC), Via del Fosso di Fiorano 64, 00143 Rome, Italy, ${ }^{3}$ Clinica Psichiatrica, Dipartimento di Neuroscienze, Università \\ Tor Vergata, Via Montpellier 1, 00133 Rome, Italy, ${ }^{4}$ Behavioural Neuroscience Laboratory, CEINGE-Biotecnologie Avanzate, Via Comunale Margherita 482, \\ 80145 Naples, Italy, ${ }^{5}$ Dipartimento di Scienze Ambientali, Seconda Università di Napoli, Via Vivaldi 43, 81100 Caserta, Italy, ${ }^{6}$ Dipartimento di Medicina \\ Sperimentale e Scienze Biochimiche, Università Tor Vergata, Via Montpellier 1, 00133 Rome, Italy, ${ }^{7}$ Dipartimento di Scienze Biomediche, Università degli \\ Studi di Teramo, Piazza Aldo Moro 45, 64100 Teramo, Italy, and ${ }^{8}$ European Brain Research Institute (EBRI), Via del Fosso di Fiorano 64, 00143 Rome, Italy
}

Interleukin-1 $\beta$ (IL-1 $\beta$ ) is involved in mood alterations associated with inflammatory illnesses and with stress. The synaptic basis of IL- $1 \beta$-induced emotional disturbances is still unknown. To address the possible involvement of the endocannabinoid system in IL- $1 \beta$ induced anxiety, we performed behavioral and neurophysiological studies in mice exposed to stress or to intracerebroventricular injections of this inflammatory cytokine or of its antagonist. We found that a single intracerebroventricular injection of IL- $1 \beta$ caused anxiety in mice, and abrogated the sensitivity of cannabinoid CB1 receptors (CB1Rs) controlling GABA synapses in the striatum. Identical behavioral and synaptic results were obtained following social defeat stress, and intracerebroventricular injection of IL-1 receptor antagonist reverted both effects. IL- $1 \beta$-mediated inhibition of CB1R function was secondary to altered cholesterol composition within membrane lipid rafts, and required intact function of the transient receptor potential vanilloid 1 (TRPV1) channel, another element of the endocannabinoid system. Membrane lipid raft disruption and inhibition of cholesterol synthesis, in fact, abrogated IL-1 $\beta$-CB1R coupling, and TRPV1-/- mice were indeed insensitive to the synaptic and behavioral effects of both IL- $1 \beta$ and stress. On the other hand, cholesterol enrichment of striatal slices mimicked the synaptic effects of IL- $1 \beta$ on CB1Rs only in control mice, while the same treatment was ineffective in slices prepared from TRPV1-I- mice. The present investigation identifies a previously unrecognized interaction between a major proinflammatory cytokine and the endocannabinoid system in the pathophysiology of anxiety.

\section{Introduction}

The role of inflammatory cytokines in the pathophysiology of mood disturbances is increasingly recognized (Dantzer et al., 2008; Miller et al., 2009). For example, high levels of proinflammatory cytokines have been found in peripheral blood and in CSF of depressed patients (Zorrilla et al., 2001), and blockade of cytokine signaling is associated with relevant mood-enhancing effects in humans (Tyring et al., 2006). In addition, systemic administration of lipopolysaccharide, which induces the expression of interleukin- $1 \beta$ (IL- $1 \beta$ ) and of other inflammatory cytokines in the brain (van Dam et al., 1992; Breder et al., 1994; Layé et al., 1994), causes depression and anxiety in healthy subjects

\footnotetext{
Received March 28, 2012; revised Aug. 7, 2012; accepted Aug. 11, 2012.

Author contributions: L.S., G.B., M.M., A.U., and D.C. designed research; S.R., F.N., V.D.C., C.M., V.S., A.M., F.B., and M.B. performed research; S.R., L.S., F.N., V.D.C., C.M., V.S., A.M., F.B., M.B., M.M., and A.U. analyzed data; D.C. wrote the paper.

This work was supported by grants from the Italian Ministry of Health to D.C.; from Fondazione Tercas (Grant 2009-2012) to M.M. and D.C.; and from the Fondazione Italiana Sclerosi Multipla (FISM 2011) to S.R. and M.M.

The authors declare no competing financial interests.

Correspondence should be addressed to Diego Centonze, Clinica Neurologica, Dipartimento di Neuroscienze, Università Tor Vergata, Via Montpellier 1, 00133 Rome, Italy. E-mail: centonze@uniroma2.it.

DOI:10.1523/JNEUROSCI.1515-12.2012

Copyright $\odot 2012$ the authors $\quad 0270-6474 / 12 / 3213896-10 \$ 15.00 / 0$
}

(Reichenberg et al., 2001; Miller at al., 2009). In line with this, the clinical use of IL-2, interferon- $\alpha$, or interferon- $\beta$ in chronic diseases has been convincingly associated with the development of anxious depression and suicidal ideation (Capuron et al., 2000; Goeb et al., 2006; Dantzer et al., 2008).

Also, ample data show that proinflammatory cytokines in rodents are involved in mood regulation and, in fact, systemic or central administration of the major inflammatory cytokine IL- $1 \beta$ causes behavioral manifestations closely resembling anxiousdepressive symptoms in humans, including anhedonia, reduced exploratory behaviors, social withdrawal, fatigue, and sleep disturbances (Dantzer et al., 2008; Miller et al., 2009). The mechanism by which inflammation exerts its mood-controlling effects is largely undetermined, although alterations of serotonin metabolism (Moreau et al., 2005; Zhu et al., 2006; Snyder, 2011) and of the hypotalamus-pituitary-adrenal (HPA) axis have been implicated (Pace et al., 2007).

The endocannabinoid system (ECS) plays a fundamental role in emotional disorders, and magnification of endocannabinoid signaling has antidepressant and antianxiety actions in humans (Hariri et al., 2009) and in rodents (Kathuria et al., 2003; Gobbi et al., 2005; Patel and Hillard, 2006; Micale et al., 2009; Rossi et al., 
2010). Conversely, blockade of type-1 cannabinoid receptors (CB1Rs) has the opposite effect in humans (Hill and Gorzalka, 2009; Topol et al., 2010) and in rodents (Beyer et al., 2010; De Chiara et al., 2010a). These data suggest an interaction between inflammatory cytokines and the ECS in emotional control, but this possibility has never been investigated so far.

Thus, the present study, by exploring the possible involvement of the ECS in this effect, was specifically designed to clarify the synaptic substrate of IL- $1 \beta$-induced anxiety. We focused on CB1Rs controlling GABA synapses $\left(\mathrm{CB} 1 \mathrm{Rs}_{(\mathrm{GABA})}\right)$ in the striatum because this brain area is emerging as a key structure in mood regulation in humans (Reiman et al., 1989; Yoo et al., 2005; Mathew and Ho, 2006) and in rodents (Nestler and Carlezon, 2006; Favilla et al., 2008; Kim et al., 2008; Zhang et al., 2008; Steiner et al., 2010). In addition, anxious-depressive behavior is associated with reduced sensitivity of striatal $\mathrm{CB} 1 \mathrm{Rs}_{(\mathrm{GABA})}$, whose activity is rescued by mood-enhancing and antianxiety pharmacological and environmental manipulations (Rossi et al., 2008; Hill and Gorzalka, 2009; De Chiara et al., 2010a,b).

\section{Materials and Methods}

Mice. Male C57BL/6 mice (8-10 weeks old) were used. Mice lacking transient receptor potential vanilloid 1 (TRPV1) channels (TRPV1-/-, Jackson Laboratory) were also used along with their matched wild-type (WT) counterparts (Maccarrone et al., 2008; Musella et al., 2009). All efforts were made to minimize animal suffering and to reduce the number of mice used, in accordance with the European Communities Council Directive of November 24, 1986 (86/609/EEC). All animals were housed, four per cage, on a $12 \mathrm{~h}$ light/dark cycle with lights on at 6 A.M.

In vivo treatments. IL- $1 \beta(1.0 \mu \mathrm{g} / \mathrm{kg})$ or IL- $1 \beta$ receptor antagonist (IL-1ra, $1.25 \mathrm{mg} / \mathrm{kg}$ ) (both dissolved in PBS; both from R\&D Systems) were administered in vivo by a single intracerebroventricular injection $(0.2 \mu \mathrm{g} / \mu \mathrm{l}$ saline $)$ under stereotaxic coordinates (from bregma: antero-posterior, $0 \mathrm{~mm}$; lateral, $0.8 \mathrm{~mm}$; depth, $2.4 \mathrm{~mm}$ from the skull) and general anesthesia with 2,2,2-tribromoethanol ( $10 \mathrm{mg} / \mathrm{ml} ; 1 / 27$ of body weight). In other experiments, a single dose of 5-iodoresiniferatoxin (I-RTX) $(0.75 \mathrm{mg} / \mathrm{kg}$ dissolved in dimethylsulfoxide (DMSO); Tocris Bioscience) was injected intraperitoneally in stressed mice. Animals receiving intracerebroventricular or intraperitoneal injections of the appropriate volume of vehicle were used as controls and, in all cases, behavioral or electrophysiological experiments were performed $24 \mathrm{~h}$ after the intracerebroventricular or intraperitoneal injections.

Psychoemotional stress. Social defeat stress (SDS) was induced as already described (Rossi et al., 2008, 2010; De Chiara et al., 2010a). Briefly, individual mice were subjected to daily bouts for $10 \mathrm{~min}$ with an aggressive CD1 resident mouse, followed by $3 \mathrm{~h}$ protected sensory contact with their aggressor. Mice were exposed to a different aggressor each day for $3 \mathrm{~d}$.

Behavior. To measure anxiety, the open field test (OFT) and the elevated plus maze (EPM) were used. The two tests were administered $2 \mathrm{~h}$ apart in random sequence in each group of animals and in their appropriate controls ( 8 mice per group). In stressed mice, intracerebroventricular IL-1ra or intraperitoneal I-RTX were administered immediately after the last session of the three consecutive daily sessions of aggression. Mice underwent the behavioral analysis $24 \mathrm{~h}$ after the injections of IL-1 $\beta$, IL-1ra, I-RTX, or the appropriate vehicles.

The OFT paradigm assesses motor activity of animals in an averse, stressful environment. This protocol was performed as previously reported (Rossi et al., 2008, 2010; De Chiara et al., 2010a). Briefly, mice were placed into the center of a clear Plexiglas arena $(25 \times 35 \times 20 \mathrm{~cm})$, where they were allowed to explore for $30 \mathrm{~min}$. Overhead incandescent light bulbs provided a 600 lux illumination inside the test chamber. Activities in the central zone, including the number of entries, the distance traveled, and total time spent in the central zone, were measured using a video tracking system (Videotrack, Viewpoint). Center distance was divided by the total distance to obtain a center/total-distance ratio used as an index of anxiety-related behavior. The total distance traveled was also extracted to provide a measure of locomotor activity, which is not confounded by any changes in anxiety.

The EPM represents one of the most widely used tests for assessing anxiety in rodents (Lister, 1987). Each mouse was placed in the center of the maze with its nose in a closed arm. The time spent in the open arms and in the closed arms of the maze was recorded as measure of anxious state. The time spent in each compartment was expressed as percentage of the total 5 min test time. The entry with all four feet into one arm was defined as an arm entry. At the end of each trial, the arena of the OFT and the maze were wiped clean.

Electrophysiology. Whole-cell patch-clamp recordings from single striatal neurons in corticostriatal coronal slices $(200 \mu \mathrm{m})$ were performed as previously described (Rossi et al., 2008; Hill and Gorzalka, 2009; De Chiara et al., 2010a,b). To detect $\mathrm{GABA}_{\mathrm{A}}$-mediated spontaneous IPSCs (sIPSCs), intraelectrode solution had the following composition (in $\mathrm{mm}$ ): $110 \mathrm{CsCl}, 30 \mathrm{~K}^{+}$-gluconate, 1.1 EGTA, $10 \mathrm{HEPES}, 0.1 \mathrm{CaCl}_{2}, 4$ Mg-ATP, $0.3 \mathrm{Na}$-GTP. MK-801 (30 $\mu \mathrm{M})$ and CNQX (10 $\mu \mathrm{M})$ were added to the external solution to block, respectively, NMDA and non-NMDA glutamate receptors.

The detection threshold of sIPSCs was set at twice the baseline noise. The fact that no false events would be identified was confirmed by visual inspection for each experiment. Offline analysis was performed on spontaneous synaptic events recorded during fixed time epochs (5-10 samplings of 2-3 min each, recorded every 2-3 min) for a total of 10-30 min analysis for each recorded neuron, depending on the length of the experiment.

Drugs used for the electrophysiological experiments were first dissolved in DMSO (HU210) or water, then in the bathing artificial CSF (ACSF) to the desired final concentration. The concentrations of the various drugs were chosen according to previous in vitro studies on corticostriatal brain slices (Rossi et al., 2008; Musella et al., 2009; De Chiara et al., 2010b) and were as follows: $3 \mu \mathrm{m}$ baclofen, $10 \mu \mathrm{M}$ CNQX, $1 \mu \mathrm{M}$ HU210, $30 \mu \mathrm{M}$ MK-801 (Tocris Bioscience); $30 \mathrm{ng} / \mathrm{ml}$ IL-1 $\beta$ (R\&D Systems). In some experiments, methyl- $\beta$-cyclodextrin (MCD, $5 \mathrm{~mm}$, first dissolved in water, Sigma-Aldrich) was applied for $30 \mathrm{~min}$ in control or IL-1 $\beta$-treated slices (Maccarrone et al., 2009). Some corticostriatal slices were also incubated with cholesterol-loaded MCD ( $5 \mathrm{~mm})$, prepared as reported (Bari et al., 2005), for $30 \mathrm{~min}$ before the application of HU210 (10 $\mathrm{min})$. In other experiments, striatal slices were incubated with mevestatin $(10 \mu \mathrm{M}$, first dissolved in ethanol; Tocris Bioscience) or with IL- $1 \beta$ plus mevestatin for $1 \mathrm{~h}$. In the experiments with drugs dissolved in DMSO or ethanol, control samplings were obtained during application of identical volumes of DMSO or ethanol in the ACSF.

Binding experiments. Samples of mouse spinal cord or striatum were resuspended in $2 \mathrm{~mm}$ Tris-EDTA, $320 \mathrm{~mm}$ sucrose, and $5 \mathrm{~mm} \mathrm{MgCl}_{2}, \mathrm{pH}$ 7.4 , and then homogenized in a Potter homogenizer and centrifuged as reported (Maccarrone et al., 2008). The resulting pellet was resuspended in assay buffer ( $50 \mathrm{~mm}$ Tris-HCl, $2 \mathrm{~mm}$ Tris-EDTA, $3 \mathrm{~mm} \mathrm{MgCl}_{2}, 1 \mathrm{~mm}$ phenylmethylsulfonyl fluoride, $\mathrm{pH}$ 7.4) to a protein concentration of 1 $\mathrm{mg} / \mathrm{ml}$. The membrane preparations were divided into aliquots that were stored at $-80^{\circ} \mathrm{C}$ for no longer than 1 week (Maccarrone et al., 2008).

Membrane fractions $(100 \mu \mathrm{g}$ of protein/test) were used with the TRPV1 agonist $\left[{ }^{3} \mathrm{H}\right]$ resinferatoxin $\left(\left[{ }^{3} \mathrm{H}\right] \mathrm{RTX}, 500 \mathrm{pM}\right)$, and the binding was evaluated by rapid filtration assays. Unspecific binding was determined in the presence of the cold agonist RTX or the selective antagonist I-RTX (both used at $1 \mu \mathrm{M}$ ), as reported (Maccarrone et al., 2008). RTX was purchased from Sigma-Aldrich, $\left[{ }^{3} \mathrm{H}\right] \mathrm{RTX}(43 \mathrm{Ci} / \mathrm{mmol})$ was from PerkinElmer Life Sciences, and I-RTX was from Tocris Bioscience.

Statistical analysis. The analyses were performed on a per-animal basis, and throughout the text " $n$ " refers to the number of mice used. Eight mice were used for each behavioral experiment, and 5-8 mice were used for a single electrophysiological experiment. Electrophysiological results from neurons recorded from the same animal were treated as a separate sample and averaged before calculating statistics. One to six neurons per animal were recorded. One or two animals per day were used for the electrophysiological experiment. For data presented as the mean \pm SEM, statistical analysis between two groups was performed using a paired or unpaired Student's $t$ test or Wilcoxon's test. Multiple comparisons were analyzed by one-way ANOVA followed by Tukey's HSD. The signifi- 
cance level of the results was established at $p<$ 0.05 . Degrees of freedom for significant $p$ values were shown.

\section{Results}

\section{Central IL-1 $\beta$ is involved in anxiety}

The emotional status of mice treated with IL- $1 \beta$ was tested $24 \mathrm{~h}$ after a single intracerebroventricular injection of this cytokine $(n=8)$ or of vehicle $(n=8)$ at the OFT and the EPM. At the OFT, the activity in the center of arena and the center/ total-distance ratio can be used as an index of anxiety-related responses, as anxiety reduces the time spent in the center of the arena (De Chiara et al., 2010a; Rossi et al., 2010). Mice receiving intracerebroventricular IL- $1 \beta$, by spending a shorter time in the center of the arena compared with vehicle-treated mice, revealed a significant increase in anxiety (center time: $345.6 \pm 22.2 \mathrm{~s}$ vs $601.2 \pm 46.6 \mathrm{~s}, t_{(14)}=$ 4.95, $p<0.001$; center entry count: $111.5 \pm 4.4$ vs $160.4 \pm 18.3, t_{(14)}=2.59$, $p<0.01$; center/total-distance ratio: $0.21 \pm 0.01$ vs $0.40 \pm 0.02, t_{(14)}=7.66$, $p<0.01)$. Locomotor activity, measured as total distance traveled at OFT, did not differ significantly between groups (vehicle i.c.v.: $6495.2 \pm 1280.0 \mathrm{~cm}$; IL-1 $\beta$ i.c.v. $6583.4 \pm 725.2 \mathrm{~cm}$; IL-1ra i.c.v.: $6396.7 \pm$ $470.8 \mathrm{~cm} ; F=0.04, p=0.98)$.

At the EPM, mice receiving intracerebroventricular IL-1 also showed increased anxiety by spending more time in the closed arms than in the open arms compared with vehicle-injected animals (percentage of time spent in open arms: $14.5 \pm 1.0 \%$ vs $41.9 \pm 2.1 \%$, $t_{(14)}=11.77, p<0.01$; percentage of time spent in closed arms: $69.8 \pm 2.1 \%$ vs $\left.38.3 \pm 3.7 \%, t_{(14)}=7.46, p<0.01\right)$. The involvement of IL- $1 \beta$ signaling was also explored in the anxious state induced by SDS (Rossi et al., 2008, 2010; De Chiara et al., 2010a). Intracerebroventricular administration of IL-1 ra immediately after the last session of 3 consecutive days of SDS significantly interfered with the development of anxiety evaluated $24 \mathrm{~h}$ later (OFT: center time: $F_{(3,28)}=20.3, p<0.0001$; center entry count: $F_{(3,28)}=8.0, p=0.0005$; center/total-distance ratio: $F_{(3,28)}=7.8$, $p<0.001$; EPM: percentage of time spent in open arms: $F_{(3,28)}=$ $10.2, p=0.0001$; percentage of time spent in closed arms: $F_{(3,28)}$ $=24.3, p<0.0001)$. In fact, intracerebroventricular IL-1ra $(n=$ 8 ) was able to block the development of the anxious state compared with stressed mice $(n=8)$ treated with intracerebroventricular vehicle (OFT: center time: $p<0.001$; center entry count: $p<0.01$; center/total-distance ratio: $p<0.05$; EPM: $p<0.001$ for both parameters). Of note, intracerebroventricular IL-1 ra had negligible effects at both the OFT and the EPM in nonstressed mice $(p>0.05$ for all parameters, compared with nonstressed mice treated with intracerebroventricular vehicle; $n=8$ for both groups) (Fig. $1 A, B)$.

\section{IL-1 $\boldsymbol{\beta}$ blocks striatal CB1Rs ${ }_{(\mathrm{GABA})}$}

Loss of sensitivity of CB1Rs controlling GABA synapses in the striatum has been shown previously to represent a synaptic coun- terpart of the anxious state induced by SDS in mice (Rossi et al., 2008, 2010; De Chiara et al., 2010a,b). Thus, we wondered whether IL- $1 \beta$ could affect the sensitivity of these receptors and in turn cause anxiety. The synaptic response to the CB1R agonist HU210 was therefore measured in brain slices from mice treated with intracerebroventricular vehicle or IL-1 $\beta$ ( $n=5$ for both groups) $24 \mathrm{~h}$ after the treatment. Intracerebroventricular IL-1 $\beta$ was able to fully block the sensitivity of CB1Rs ${ }_{(\mathrm{GABA})}(p>0.05$ compared with pre-HU210 values), while HU210 caused the expected reduction of sIPSC frequency in mice receiving intracerebroventricular vehicle $\left(t_{(4)}=4.31, p<0.01\right)$ (Fig. $2 A$ ). IL- $1 \beta$ was able to block CB1Rs (GABA) even when applied in the bathing solution of corticostriatal slices of naive mice $(n=12, p>0.05$ compared with pre-HU210) (Fig. $2 B$ ), indicating that IL-1 $\beta$ 's effect on these receptors is mediated centrally and does not follow, for example, the activation of the HPA axis in intact mice treated with intracerebroventricular IL-1 $\beta$ (Pace et al., 2007). Circulating corticosterone secondary to the activation of the HPA axis, in fact, is also known to penetrate the brain, and to cause loss of $\mathrm{CB}_{1 \mathrm{R}}(\mathrm{GABA})$ sensitivity within the striatum (Rossi et al., 2008, 2010).

The involvement of CB1Rs ${ }_{(\mathrm{GABA})}$ in the mood-regulating effect of IL- $1 \beta$ was also explored in stressed mice treated with intracerebroventricular IL-1ra. As reported (Rossi et al., 2008, 2010; De Chiara et al., 2010a,b), the anxious behavior of mice exposed to SDS only receiving intracerebroventricular vehicle was associated with abrogated sensitivity of GABAergic sIPSCs to HU210 ( $n=7, p>0.05$ compared with pre-HU210) (Fig. 2C). 
A

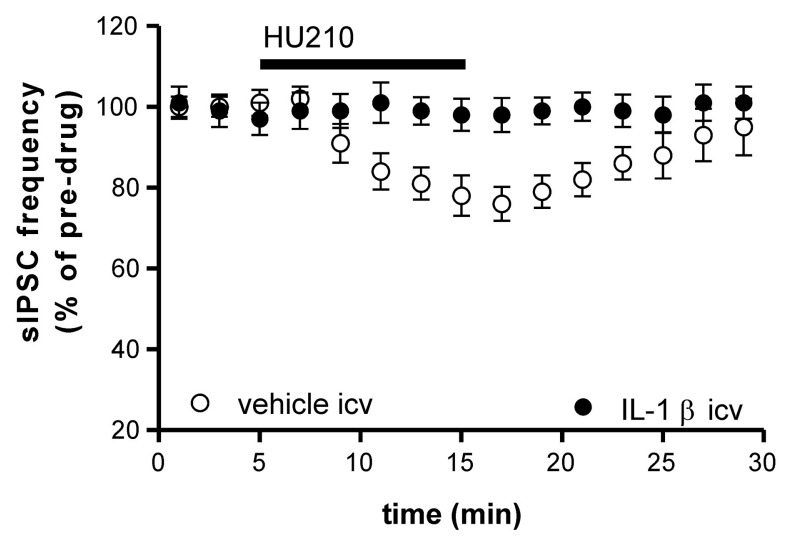

C

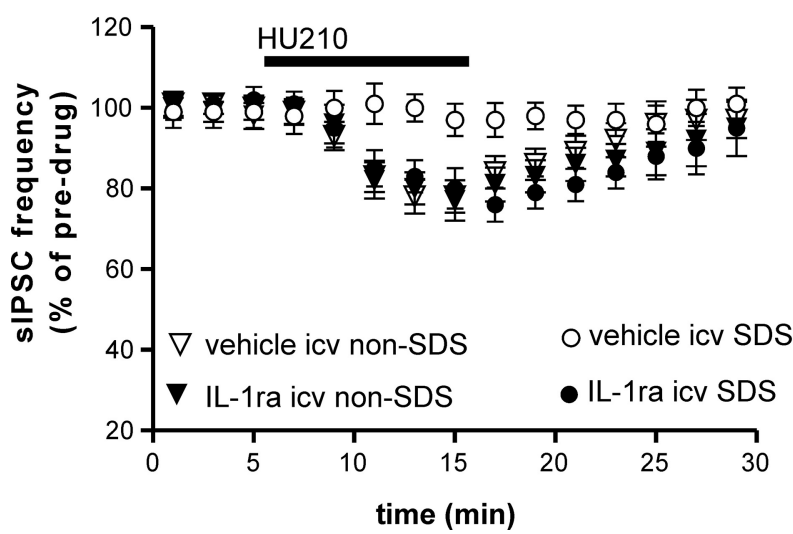

B

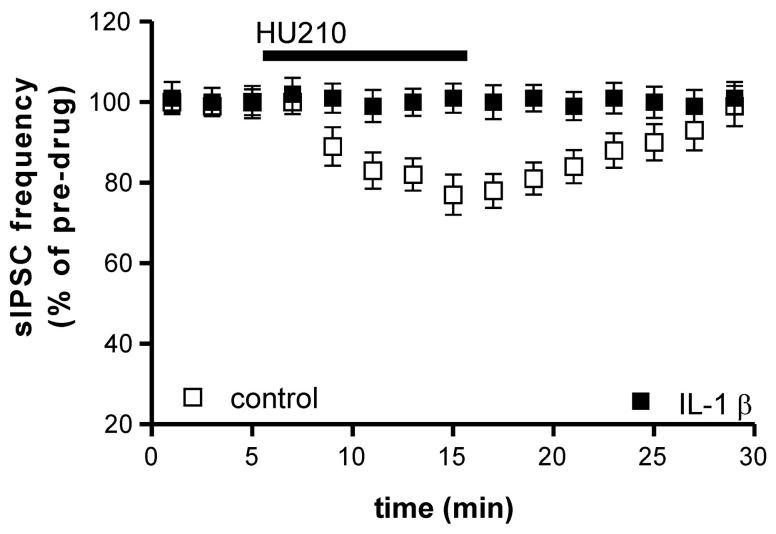

vehicle icv SDS vehicle icv

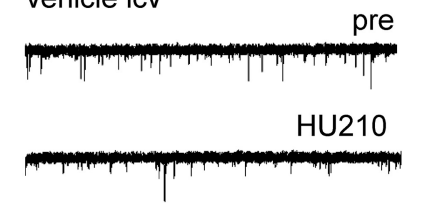

IL-1 $\beta$ icv

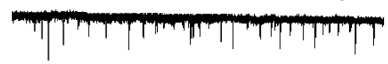

HU210

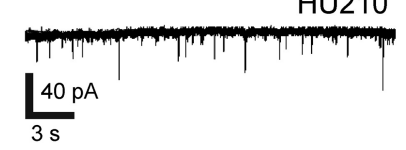

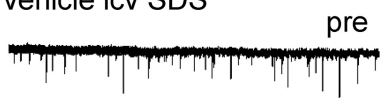

HU210

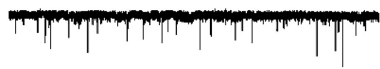

IL-1ra icv SDS

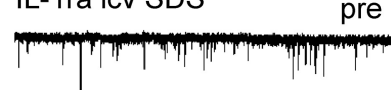

HU210

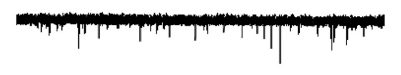

Figure 2. IL-1 $\beta$ blocks (B1Rs controlling GABA synapses in the striatum. $A, B$, Graphs show that the depressant effect of the CB1 receptor agonist HU210 on sIPSC frequency was abolished by IL-1 $\beta$ intracerebroventricular injection ( $A, n=5$ for both experimental groups) or by incubation of striatal slices with IL-1 $\beta(B, n=12)$. $C$, HU210-induced reduction of sIPSC frequency was lost in stressed mice $(n=7)$, but it was normal in stressed mice treated with intracerebroventricular injection of IL-1ra $(n=6)$, and in nonstressed mice treated with intracerebroventricular IL-1ra ( $n=$ 8). The electrophysiological traces on the right are examples of voltage-clamp recordings showing the loss of sIPSC frequency reduction induced by HU210 in a neuron from IL-1 $\beta$ intracerebroventricular-treated mice, and the recovery of the effects of HU210 induced by intracerebroventricular IL-1ra in another neuron from a stressed mouse.

Blockade of IL-1 $\beta$ signaling with intracerebroventricular IL-1ra in mice exposed to SDS was conversely associated with normal response to the pharmacological stimulation of $\mathrm{CB} 1 \mathrm{Rs}_{(\mathrm{GABA})}$ $\left(n=6, t_{(5)}=4.13, p<0.01\right.$ compared with pre-HU210). Of note, intracerebroventricular IL-1 ra did not potentiate HU210 responses in nonstressed mice $(n=8, p>0.05$ compared to HU210 responses in nonstressed mice receiving i.c.v. vehicle or IL-1ra) (Fig. 2C), which is consistent with behavioral results showing that this inhibitor does not produce antianxiety effects in nonstressed mice. These findings are also in keeping with previous results showing that potentiation of HU210 responses is only seen in association with pharmacological and environmental manipulations causing antianxiety effects in nonstressed mice (De Chiara et al., 2010a).

$\mathrm{GABA}_{\mathrm{B}}$ receptors are insensitive to IL-1 $\beta$

Along with $\mathrm{CB} 1 \mathrm{Rs}_{(\mathrm{GABA})}$, striatal GABA synapses are controlled by other receptor subtypes inhibiting transmitter release. Thus, we investigated whether the effect of IL- $1 \beta$ on sIPSCs was specific for $\mathrm{CB} 1 \mathrm{Rs} \mathrm{GABA}_{(\mathrm{GA})}$ or also involved $\mathrm{GABA}_{\mathrm{B}}$ receptors. As reported (De Chiara et al., 2010b), application of the $\mathrm{GABA}_{\mathrm{B}}$ receptor agonist baclofen $(n=6)$ significantly $\left(t_{(5)}=7.76, p<0.01\right)$ reduced striatal sIPSC frequency in control slices. In slices incubated with IL- $1 \beta$, the inhibitory effect of baclofen was similar to that seen under control conditions $(n=7, p>0.05$, compared with baclofen in control slices) (Fig. $3 A$ ).

Involvement of cholesterol metabolism in IL-1 $\beta$-mediated suppression of $\mathrm{CB} 1 \mathrm{Rs}_{(\mathrm{GABA})}$

Striatal CB1Rs ${ }_{(\mathrm{GABA})}$ function within lipid rafts, which are subdomains of the plasma membranes that contain high concentrations of cholesterol (Lister, 1987; De Chiara et al., 2010b). IL-1 $\beta$ has been already demonstrated to increase cholesterol intracellular accumulation (Zhang et al., 2011), raising the possibility that altered lipid composition in rafts might mediate the effects of

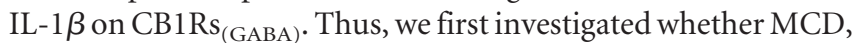
which causes a significant depletion of cholesterol in striatal slices (Maccarrone et al., 2009), was able to reverse the effects of IL-1 $\beta$ on $\mathrm{CB}_{1 \mathrm{R}}(\mathrm{GABA})$ sensitivity. As already reported (Maccarrone et al., 2009; De Chiara et al., 2010b), preincubation of striatal slices with MCD did not increase per se the sensitivity of CB1Rs ${ }_{(\mathrm{GABA})}$ to HU210 ( $n=5, p>0.05$ compared with HU210 in control slices). MCD, however, was able to rescue the effect of HU210 on sIPSC frequency after IL- $1 \beta$ administration in vitro $\left(n=6, t_{(5)}=\right.$ $4.89, p<0.05$ compared with pre-HU210) (Fig. 3B).

We also explored the effect of mevastatin, an inhibitor of cholesterol synthesis able to block cholesterol accumulation in lipid 
rafts (Suzuki et al., 2007; De Chiara et al., 2010b). As with MCD, mevastatin did not affect the sensitivity of $\mathrm{CB} \mathrm{Rs}_{(\mathrm{GABA})}$ to HU210 ( $n=6, p>0.05$ compared with HU210 in control slices), but significantly interfered with IL- $1 \beta$-induced suppression of HU210 effects $\left(n=6, t_{(5)}\right.$ $=5.81, p<0.05$ compared with preHU210) (Fig. 3C).

Involvement of TRPV1 channels in the synaptic effects of IL-1 $\beta$

We then tried to detail the mechanism responsible for IL- $1 \beta$-mediated inhibition of $\mathrm{CB}_{1 \mathrm{R}}(\mathrm{GABA})$ function. We have already found that stimulation of TRPV1 channels inhibits the signaling at striatal CB1Rs $_{(\mathrm{GABA})}$ (Maccarrone et al., 2008; Musella et al., 2010), and we postulated, therefore, that these channels could also play a role in the effect of IL- $1 \beta$ on these receptors. IL-1 $\beta$, applied intracerebroventricularly $(n=6)$ or in the slice bathing solution $(n=6)$, failed to block the sensitivity of CB1Rs (GABA) to HU210 in mice lacking TRPV1 channels (i.c.v. IL$1 \beta: t_{(5)}=6.09, p<0.01$ compared with pre-HU210 values; IL-1 $\beta$ applied in slice: $t_{(5)}=8.31, p<0.01$ compared with preHU210 values), indicating that these channels are essential for the synaptic effects of IL-1 $\beta$ (Fig. $4 A, B$ ). HU210 responses were not potentiated in slices from TRPV $1-/-$ mice either in the absence $(n=6)$ or in the presence $(n=6)$ of IL-1 $\beta$ ( $p>0.05$ compared with HU210 responses in WT mice) (Fig. $4 B$ ).

The effect of HU210 on sIPSC frequency was also normal in TRPV1-/mice exposed to the SDS protocol $(n=5)$ $\left(t_{(8)}=3.03, p<0.01\right.$ compared with stressed WT mice), and in WT mice treated at the end of the SDS protocol with a single intraperitoneal injection of I-RTX $(n=6)$, a selective blocker of TRPV 1 channels $\left(t_{(10)}=4.34, p<0.01\right.$, compared with stressed mice receiving i.p. vehicle) (Fig. 4C,D). These data indicate, therefore, the involvement of TRPV 1 channels in IL- $1 \beta$ signaling activated by stress.

TRPV1 channels are activated by a variety of chemical and physical stimuli, which include vanilloid compounds, voltage, heat, protons, and lipid molecules, such as endocannabinoids and eicosanoids (Starowicz et al., 2007, 2008). The promiscuity of these receptor channels and the results above led us to postulate that IL- $1 \beta$ could also bind to and activate TRPV1 channels. However, the binding of the TRPV1 agonist $\left[{ }^{3} \mathrm{H}\right] \mathrm{RTX}$ was not affected by the presence of IL- $1 \beta$ in either striatum or spinal cord ( $p>0.05, n=3$ in both cases), ruling out the possibility of a direct action of IL- $1 \beta$ on TRPV 1 channels (Fig. 4E,F).
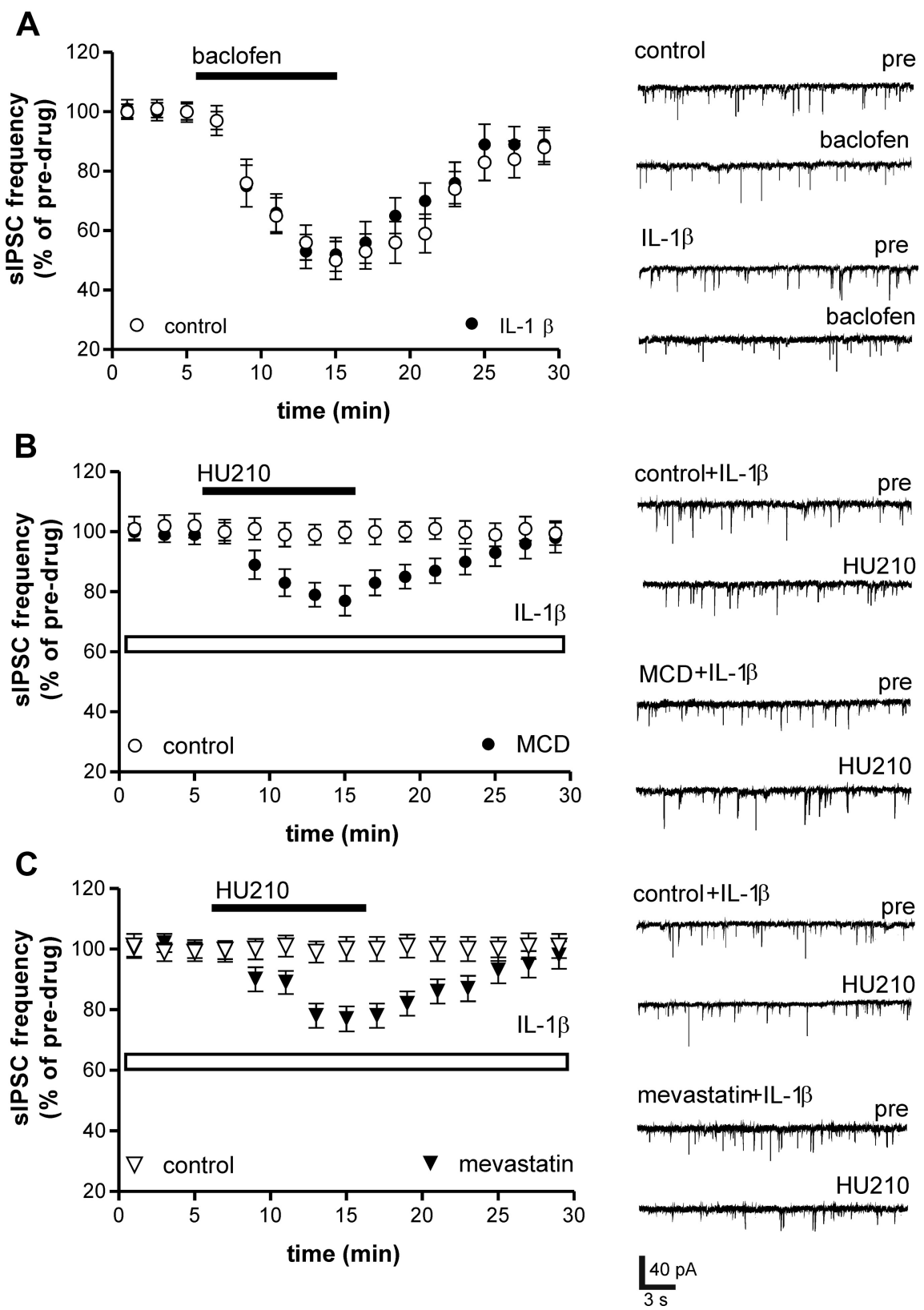

Figure 3. Involvement of cholesterol metabolism in the IL-1 $\beta$-mediated suppression of striatal $\mathrm{CB} 1 \mathrm{Rs} \mathrm{G}_{(\mathrm{GABA})}$. $\boldsymbol{A}, \mathrm{IL}-1 \beta$ failed to affect the depressant effect of $G A B A_{B}$ receptor agonist baclofen on sIPSC frequency in neurons from striatal slices (control condition: $n=6 ; \mathrm{IL}-1 \beta: n=7)$. $\boldsymbol{B}, \mathrm{MCD}$, which causes a significant depletion of cholesterol in striatal slices, was able to rescue the effect of HU210 on sIPSC frequency after IL- $1 \beta$ administration in vitro (control condition: $n=5 ; M C D: n=6$ ). C, Similarly, pharmacological inhibition of cholesterol synthesis with mevastatin also prevented IL- $1 \beta$-induced suppression of HU210 effects (control condition: $n=6$; mevastatin: $n=6$ ). The electrophysiological traces on the right are examples of voltage-clamp recordings.

\section{Cholesterol-loaded MCD blocks CB1Rs $s_{(\mathrm{GABA})}$ in WT but not in TRPV1-/- mice}

The results above show that both membrane cholesterol and TRPV1 channels are essential for the synaptic effect of IL- $1 \beta$, but do not clarify whether cholesterol is important for TRPV1 channels to exert their control on striatal $\mathrm{CB} 1 \mathrm{R}_{(\mathrm{GABA})}$ function. We addressed this possibility by measuring the effects of membrane cholesterol enrichment in control and TRPV1-/- mice. Membrane cholesterol enrichment with cholesterol-loaded MCD fully blocked the sensitivity of CB1Rs (GABA to HU210, thereby mimicking the effects of IL- $1 \beta$ on striatal sIPSCs $(n=7, p>0.05$ compared with pre-HU210 values). In slices from TRPV1-/- 

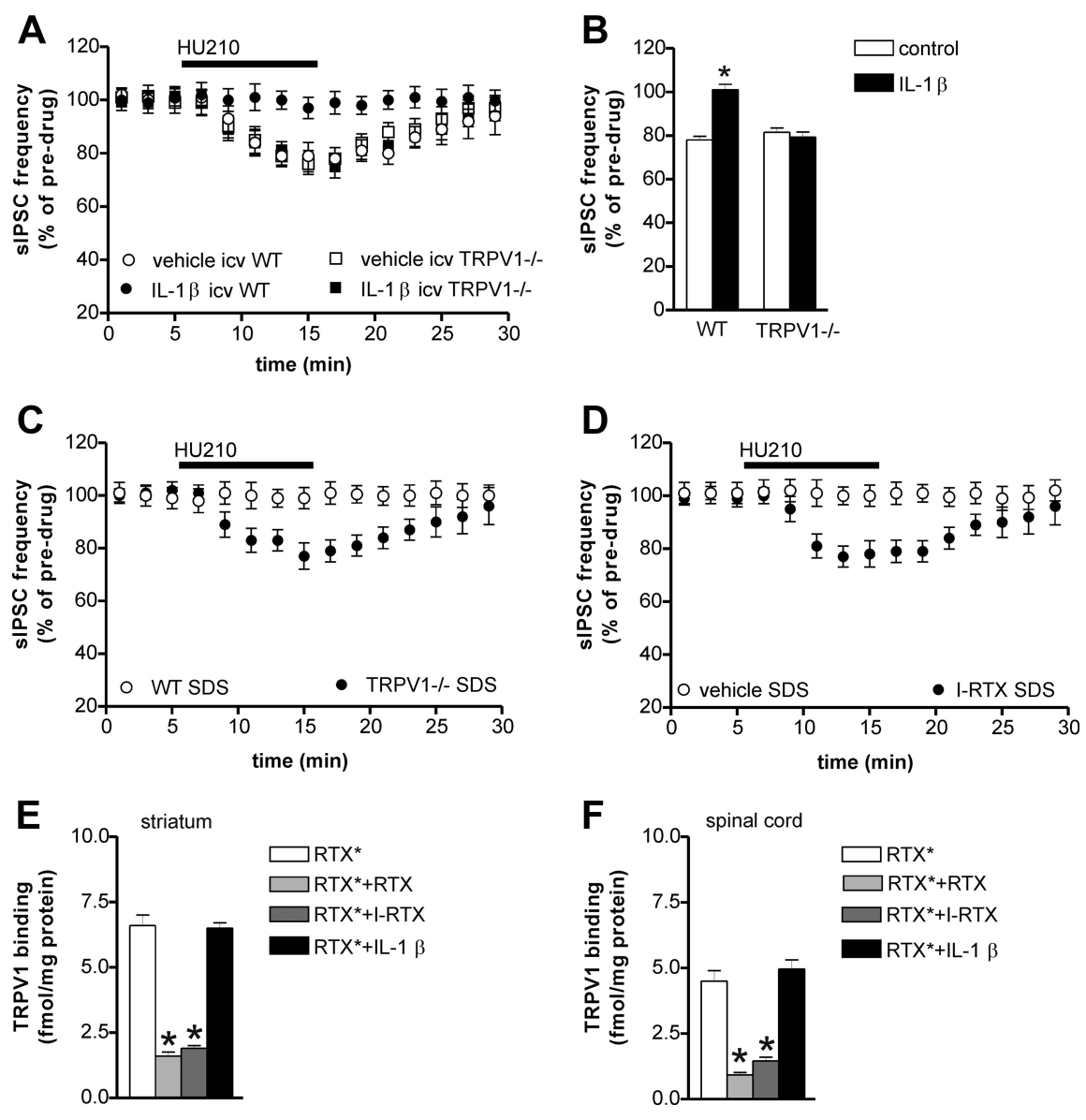

Figure 4. Involvement of TRPV1 channels in IL-1 $\beta$-mediated suppression of striatal $\mathrm{CB} 1 \mathrm{Rs}(\mathrm{GABA}) \cdot A, B, \mathrm{IL}-1 \beta$, applied intracerebroventricularly $(\boldsymbol{A}, n=6)$ or in the slice bathing solution $(\boldsymbol{B}, n=6)$, failed to block the sensitivity of $\mathrm{CB} 1 \mathrm{Rs}_{(\mathrm{GABA})}$ to $\mathrm{HU} 210$ in mice lacking TRPV1 channels. $C, D, S D S$ failed to block the sensitivity of CB1Rs $_{(G A B A)}$ to HU210 in mice lacking TRPV1 channels $(C, n=5)$ or in WT mice treated with a single intraperitoneal injection of I-RTX, a blocker of TRPV1 channels $(\boldsymbol{D}, n=6) . \boldsymbol{E}, \boldsymbol{F}$, Histograms show that the binding of TRPV1 agonist $\left[{ }^{3} H\right] R T X\left(R T X^{*}\right)$ was not affected by the presence of IL-1 $\beta$ either in the striatum $(\boldsymbol{E}, n=3)$ or in the spinal cord $(\boldsymbol{F}, n=3)$. Unspecific binding was determined in the presence of the cold agonist RTX or of the selective antagonistI-RTX. ${ }^{*} p<0.05$.

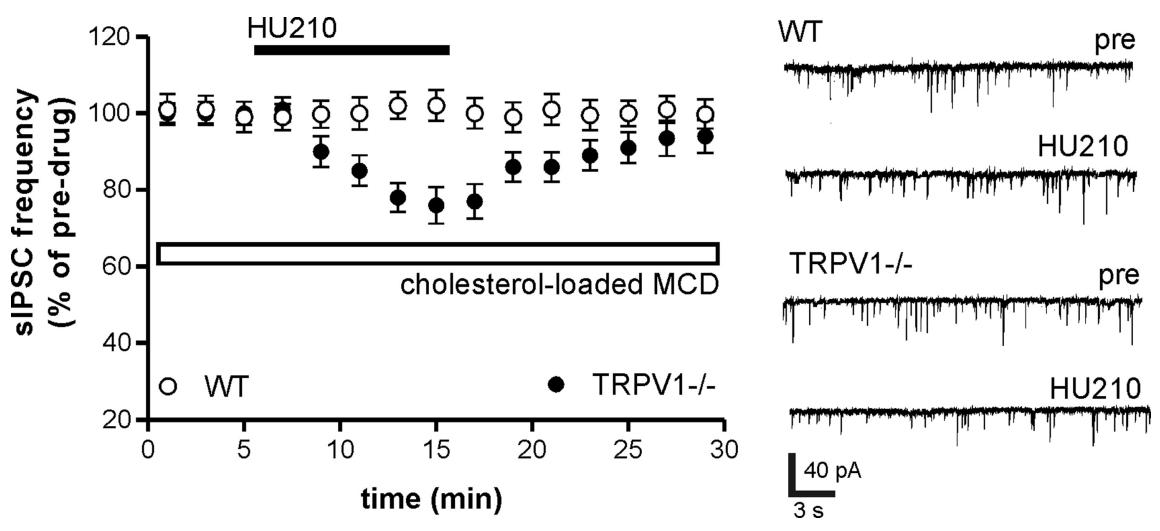

Figure 5. Involvement of TRPV1 channels in membrane cholesterol control of CB1R function. Cholesterol-loaded MCD failed to block the effect of HU210 on sIPSC frequency in TRPV1 - / - mice (WT mice: $n=7$; TRPV1 - / - mice: $n=8$ ). The electrophysiological traces below are examples of voltage-clamp recordings from WT and TRPV1 - / - mice.

mice, however, cholesterol-loaded MCD did not alter HU210 effects ( $n=8, p<0.01$ compared with pre-HU210), suggesting that IL- $1 \beta$ induced membrane cholesterol increase requires intact TRPV1 channel function to suppress the activity of CB1Rs (GABA) $_{\text {(Fig. }}$ 5). In this respect, it seems of interest that a cholesterol-binding site has been recently described in TRPV1 channels (Picazo-Juárez et al.,
2011), suggesting that their function might depend on membrane cholesterol content.

Involvement of TRPV1 channels in the behavioral effects of IL-1 $\beta$

TRPV1 channels played a crucial role also in the behavioral effects of IL- $1 \beta$. Intracerebroventricular IL-1 $\beta$, in fact, failed to provoke anxiety in TRPV1-/- mice, because both OFT and EPM evaluations gave comparable results in TRPV1-/mice receiving intracerebroventricular IL-1 $\beta(n=8)$ or intracerebroventricular vehicle $(n=8)(p>0.05$ for all parameters), and in the corresponding WT animals injected with vehicle (Fig. 6A,B). Also locomotor activity, measured as total distance traveled at the OFT, did not differ significantly between groups $(F=0.92$, $p=0.44$; data not shown). In line with the synaptic data, TRPV1-/- mice were also insensitive to the behavioral consequences of stress, because the SDS protocol applied to these animals $(n=8)$ did not cause anxiety at the OFT and at the EPM, compared with WT mice $(p>0.05$ for all parameters) (Fig. $6 C, D)$.

\section{Discussion}

The present investigation identifies a previously unrecognized interaction between a major proinflammatory cytokine and endocannabinoid-binding receptors, and provides for the first time a plausible synaptic mechanism at the basis of anxiety associated with the inflammatory response. It also points to central IL- $1 \beta$ signaling as a critical player in anxiety secondary to environmental stress, confirming a wider role of this cytokine in emotional disorders (Goshen et al., 2008; Koo and Duman, 2009; Norman et al., 2010). In fact, while mice exposed to environmental (Starowicz et al., 2008) or physical (Norman et al., 2010) stressful conditions display anxious-depressive-like symptoms, their brains increase expression of IL-1. Instead, studies involving genetic deletion of IL-1 receptor (Goshen et al., 2008) and those involving systemic (Norman et al., 2010) or central administration of IL-1ra (present study) using mice that were not exposed to stressful paradigms, found that these mice spent more time than control mice in the open arms of the EPM. Transgenic mice overexpressing IL-1ra likewise spent more time than control mice in the open arms of the EPM (Oprica et al., 2005). Most notably, higher mRNA and protein expression of IL- $1 \beta$ has also been described in postmortem brain specimens of individuals with idiopathic bipolar disorder (Rao et al., 2010).

Injection of IL-1ra only after the final day of SDS was sufficient to interfere with the behavioral and synaptic consequences 
of stress evaluated $24 \mathrm{~h}$ later. This evidence might suggest that SDS-induced neuroadaptive changes need time to appear or that they are reversible. We have previously demonstrated that $1 \mathrm{~d}$ of SDS causes only a partial suppression of the sensitivity of $\mathrm{CB}_{1 \mathrm{R}}(\mathrm{GABA})$ to $\mathrm{HU} 210$, which is instead complete after $3 \mathrm{~d}$ (Rossi et al., 2008). Furthermore, we have also described the spontaneous rescue of CB1R (GABA) function $3 \mathrm{~d}$ after the last session of stress (Rossi et al., 2008), and the ability of some environmental (running wheel, sucrose drinking) or pharmacological manipulations (cocaine), known to activate the dopamine-dependent reward pathway, to accelerate the full recovery of $\mathrm{CB} 1 \mathrm{R}_{(\mathrm{GABA})}$ sensitivity and of the anxious behavior (Rossi et al., 2008, 2010; De Chiara et al., 2010a). Thus, the data with IL-1ra after SDS are in line with these previous results, and might indicate that this antagonist mimics the effect of cocaine, running wheel, or sucrose because it activates the reward system inhibited by IL-1 $\beta$ signaling triggered by stress. In this respect, a bulk of existing literature has already demonstrated the negative interference of IL- $1 \beta$ with nigrostriatal dopamine system (Barnum et al., 2008; Chung et al., 2010; Long-Smith et al., 2010).

In the CNS, several G-protein-coupled receptors (GPCRs), including $\mathrm{CB}_{1} \mathrm{R}_{(\mathrm{GABA})}$ (Maccarrone et al., 2009; De Chiara et al., 2010b), segregate within lipid rafts, and cholesterol is essential for their function by controlling the fluidity of membranes, thus affecting the freedom of movements of lipid raft-associated proteins, as well as the ability of vesicles to deform and fuse with plasma membranes (Suzuki et al., 2007; Maccarrone et al., 2011). In addition, cholesterol can modulate the activity of GPCRs by promoting receptor dimerization and hence reducing agonist binding (Cherezov et al., 2007; Rosenbaum et al., 2007). We have demonstrated that IL- $1 \beta$ controls striatal $\mathrm{CB} \mathrm{R}_{(\mathrm{GABA})}$ activity by regulating cholesterol metabolism, extending for the first time to neuronal elements the described effects of IL- $1 \beta$ on cholesterol synthesis in other cell types (Zhang et al., 2011).

A further novel finding of this study is the evidence that IL-1 $\beta$ is an indirect regulator of another element of the ECS, namely TRPV1 channels, and that these channels exert a permissive role in the IL- $1 \beta-$ CB1R interaction, likely because they are sensitive to cholesterol content within lipid rafts. Accordingly, we have found that cholesterol enrichment of striatal slices mimicked the synaptic effects of IL- $1 \beta$ on CB1Rs $(\mathrm{GABA})$ only in control mice, while the same treatment was ineffective in slices prepared from TRPV1-/ - mice. These findings indicate therefore that TRPV1 effects on CB1R function are regulated by membrane cholesterol
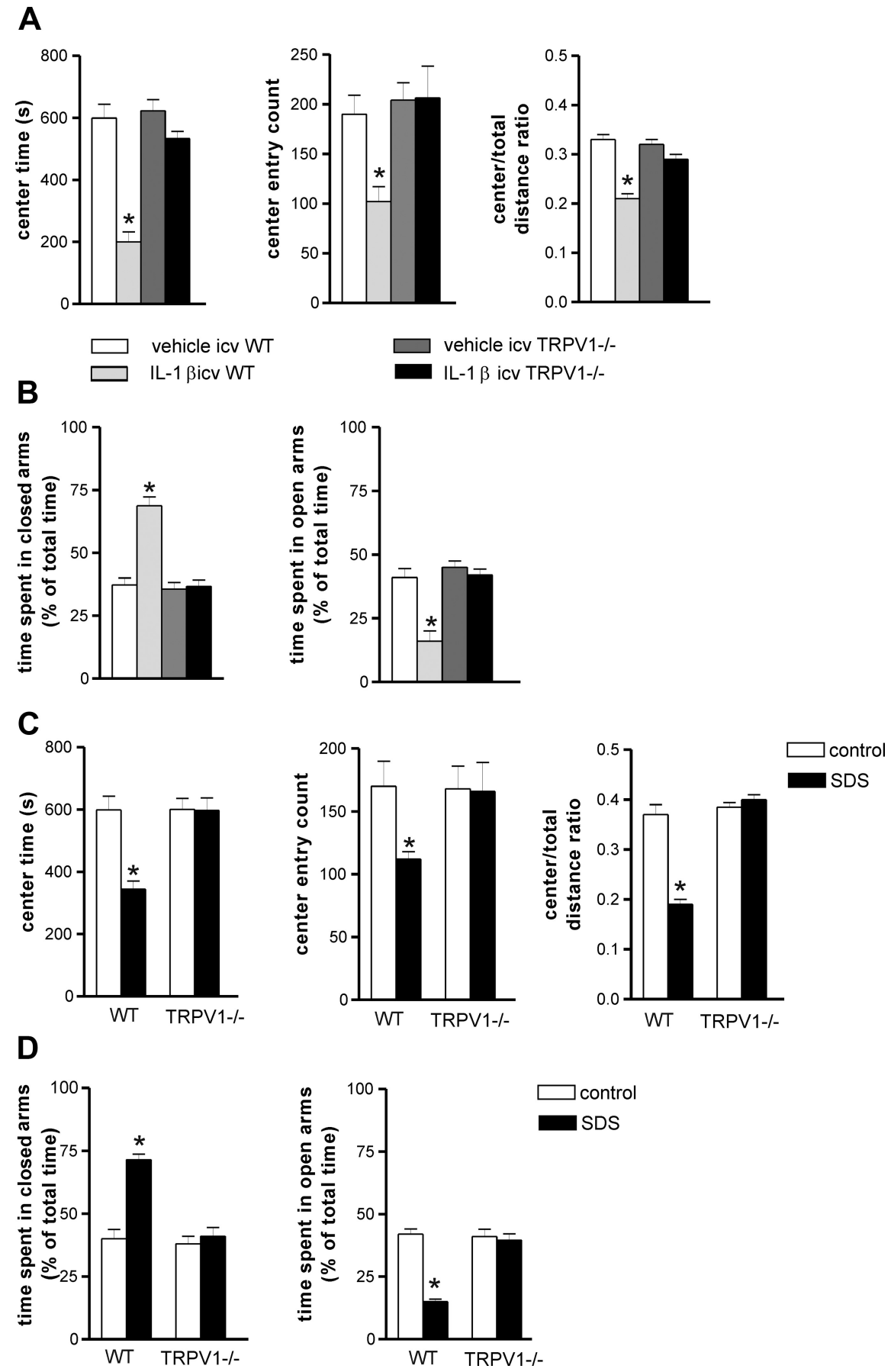

Figure 6. Involvement of TRPV1 channels in the behavioral effects of IL-1 $\beta . A, B$, Intracerebroventricular IL-1 $\beta$ failed to provoke anxiety in TRPV1 $-/$ - mice both at the OFT $(\boldsymbol{A})$ and EPM (B) evaluations. $\boldsymbol{C}, \boldsymbol{D}$, SDS protocol applied to TRPV1 $-1-$ mice did not cause anxiety at the OFT $(\boldsymbol{C})$ and at the EPM $(\boldsymbol{D})$ compared with WT mice. ${ }^{*} p<0.05 ; n=8$ for each experimental group.

content, and are consistent with recent evidence demonstrating a cholesterol-binding site in TRPV1 channels (Picazo-Juárez et al., 2011).

To support the role of TRPV1 channels in CB1R function and mood control, previous studies have already reported that pharmacological stimulation of TRPV1 channels with capsaicin interferes with the synthesis of the endocannabinoid 2-arachidonoyl-glycerol and with striatal $\mathrm{CB} 1 \mathrm{R}_{(\mathrm{GABA})}$ signaling (Maccarrone et al., 2008; Musella et al., 2010), while intracerebroventricular capsaicin injection results in anxiogenic effects in mice (Manna and Umathe, 2011). 
The mechanism by which stimulation of TRPV1 channels dampens striatal $\mathrm{CB} 1 \mathrm{R}_{(\mathrm{GABA})}$ activation by its endogenous agonist has been described in a previous report, and involves a complex intracellular pathway that also includes the regulation of gluthatione metabolism and, hence, of endocannabinoid tone (Maccarrone et al., 2008). Meanwhile, other receptor subtypes also involved in the presynaptic control of striatal GABA transmission do not seem to be under the control of IL- $1 \beta$ because this proinflammatory failed to affect the inhibition of sIPSC frequency caused by the GABAB receptor agonist baclofen.

The involvement of striatal neuron activity in the control of anxiety-related behavior in humans (Yoo et al., 2005; Mathew and Ho, 2006) and in rodents (Favilla et al., 2008) has been recently emphasized. In this respect, GABA-mediated inhibition of striatal neuron activity possibly disrupts a circuitry normally limiting fearful or anxiety-related behaviors (Rogan et al., 2005), and enhancement of cAMP signaling in the striatum has been associated with increased anxious-depressive behavior in mice (Favilla et al., 2008; Zhang et al., 2008). This information confirms the relevance of our findings for the pathophysiology of emotional disorders. CB1Rs, in fact, reduce transmitter release by inhibiting cAMP levels in presynaptic nerve terminals (Howlett et al., 2004), implying that IL- $1 \beta$-mediated inhibition of CB1R sensitivity results in enhanced cAMP signaling in neuronal elements. Of note, the involvement of striatal $\mathrm{CB} 1 \mathrm{Rs}_{(\mathrm{GABA})}$ in emotional control has been defined in previous studies showing that the anxious phenotype of mice exposed to SDS is associated with loss of sensitivity of these receptors in the striatum (Rossi et al., 2008, 2010), and that potentially rewarding experiences contrast the behavioral consequences of stress by enhancing $\mathrm{CB}_{1} \mathrm{R}_{(\mathrm{GABA})}$ function (De Chiara et al., 2010a,b). In addition, intrastriatal selective infusion of BDNF elicits a depressive behavior in mice (Eisch et al., 2003), and the anxious behavior induced by the SDS protocol used in the present study is abolished by blockade of BDNF signaling in this brain area (Berton et al., 2006). These data therefore confirm the crucial role of the striatum in mood regulation, and also emphasize the relevance of striatal $\mathrm{CB} 1 \mathrm{R}_{(\mathrm{GABA})}$ within lipid raft in emotional control, as BDNF has been found to block these receptors through a mechanism involving cholesterol metabolism (De Chiara et al., 2010b).

Among the various elements of the ECS, not only CB1Rs (Hill and Gorzalka, 2009; Beyer et al., 2010; De Chiara et al., 2010a; Topol et al., 2010), but also TRPV1 channels have been identified as possible players in mood regulation. In particular, pharmacological stimulation of TRPV1 channels generates anxiety in rodents (Campos and Guimarães, 2009) and limits the antianxiety effects of simultaneous activation of CB1Rs (Micale et al., 2009). In addition, TRPV1-/- mice exhibit reduced anxiety evaluated at the light/dark test and at the EPM compared with their WT littermates (Marsch et al., 2007), although our results showing similar behavioral responses at the OFT and the EPM in TRPV1-/- and in WT mice receiving intracerebroventricular injections of saline indicate a certain sensitivity of these mutants to the stress inherent in the surgical procedure. The synaptic basis of the antianxiety effect of pharmacological or genetic inactivation of TRPV1 channels was not clarified in those previous studies, and likely lies on the preservation of $\mathrm{CB}_{1} \mathrm{R}_{(\mathrm{GABA})}$ function, as our results seem to indicate.
Anxiety and depression are frequent and severe psychiatric conditions that occur in the absence or in the presence of concomitant medical or neurological conditions. Largely because the neurobiological bases of mood disorders are incompletely understood, only a limited proportion of these patients have a satisfactory response to current medications. Targeting IL-1 $\beta-$ CB1R interaction might represent a novel route for the treatment of anxiety associated or not with systemic or neuroinflammatory diseases in humans.

\section{References}

Bari M, Battista N, Fezza F, Finazzi-Agrò A, Maccarrone M (2005) Lipid rafts control signaling of type-1 cannabinoid receptors in neuronal cells. Implications for anandamide-induced apoptosis. J Biol Chem 280:12212-12220. CrossRef Medline

Barnum CJ, Eskow KL, Dupre K, Blandino P Jr, Deak T, Bishop C (2008) Exogenous corticosterone reduces L-DOPA-induced dyskinesia in the hemi-parkinsonian rat: role for interleukin-1beta. Neuroscience 156: 30-41. CrossRef Medline

Berton O, McClung CA, Dileone RJ, Krishnan V, Renthal W, Russo SJ, Graham D, Tsankova NM, Bolanos CA, Rios M, Monteggia LM, Self DW, Nestler EJ (2006) Essential role of BDNF in the mesolimbic dopamine pathway in social defeat stress. Science 311:864-868. CrossRef Medline

Beyer CE, Dwyer JM, Piesla MJ, Platt BJ, Shen R, Rahman Z, Chan K, Manners MT, Samad TA, Kennedy JD, Bingham B, Whiteside GT (2010) Depression-like phenotype following chronic CB1 receptor antagonism. Neurobiol Dis 39:148-155. CrossRef Medline

Breder CD, Hazuka C, Ghayur T, Klug C, Huginin M, Yasuda K, Teng M, Saper CB (1994) Regional induction of tumor necrosis factor alpha expression in the mouse brain after systemic lipopolysaccharide administration. Proc Natl Acad Sci U S A 91:11393-11397. CrossRef Medline

Campos AC, Guimarães FS (2009) Evidence for a potential role for TRPV1 receptors in the dorsolateral periaqueductal gray in the attenuation of the anxiolytic effects of cannabinoids. Prog Neuropsychopharmacol Biol Psychiatry 33:1517-1521. CrossRef Medline

Capuron L, Ravaud A, Dantzer R (2000) Early depressive symptoms in cancer patients receiving interleukin 2 and/or interferon alfa-2b therapy. J Clin Oncol 18:2143-2151. Medline

Cherezov V, Rosenbaum DM, Hanson MA, Rasmussen SG, Thian FS, Kobilka TS, Choi HJ, Kuhn P, Weis WI, Kobilka BK, Stevens RC (2007) High-resolution crystal structure of an engineered human beta2adrenergic $G$ protein-coupled receptor. Science 318:1258-1265. CrossRef Medline

Chung YC, Kim SR, Jin BK (2010) Paroxetine prevents loss of nigrostriatal dopaminergic neurons by inhibiting brain inflammation and oxidative stress in an experimental model of Parkinson's disease. J Immunol 185: 1230-1237. CrossRef Medline

Dantzer R, O'Connor JC, Freund GG, Johnson RW, Kelley KW (2008) From inflammation to sickness and depression: when the immune system subjugates the brain. Nat Rev Neurosci 9:46-56. CrossRef Medline

De Chiara V, Errico F, Musella A, Rossi S, Mataluni G, Sacchetti L, Siracusano A, Castelli M, Cavasinni F, Bernardi G, Usiello A, Centonze D (2010a) Voluntary exercise and sucrose consumption enhance cannabinoid CB1 receptor sensitivity in the striatum. Neuropsychopharmacology 35:374387. CrossRef Medline

De Chiara V, Angelucci F, Rossi S, Musella A, Cavasinni F, Cantarella C, Mataluni G, Sacchetti L, Napolitano F, Castelli M, Caltagirone C, Bernardi G, Maccarrone M, Usiello A, Centonze D (2010b) Brain-derived neurotrophic factor controls cannabinoid CB1 receptor function in the striatum. J Neurosci 30:8127-8137. CrossRef Medline

Eisch AJ, Bolaños CA, de Wit J, Simonak RD, Pudiak CM, Barrot M, Verhaagen J, Nestler EJ (2003) Brain-derived neurotrophic factor in the ventral midbrain-nucleus accumbens pathway: a role in depression. Biol Psychiatry 54:994-1005. CrossRef Medline

Favilla C, Abel T, Kelly MP (2008) Chronic G $\alpha$ s signaling in the striatum increases anxiety-related behaviors independent of developmental effects. J Neurosci 28:13952-13956. CrossRef Medline

Gobbi G, Bambico FR, Mangieri R, Bortolato M, Campolongo P, Solinas M, Cassano T, Morgese MG, Debonnel G, Duranti A, Tontini A, Tarzia G, Mor M, Trezza V, Goldberg SR, Cuomo V, Piomelli D (2005) Antidepressant-like activity and modulation of brain monoaminergic 
transmission by blockade of anandamide hydrolysis. Proc Natl Acad Sci U S A 102:18620-18625. CrossRef Medline

Goeb JL, Even C, Nicolas G, Gohier B, Dubas F, Garré JB (2006) Psychiatric side effects of interferon-beta in multiple sclerosis. Eur Psychiatry 21:186-193. CrossRef Medline

Goshen I, Kreisel T, Ben-Menachem-Zidon O, Licht T, Weidenfeld J, Ben-Hur T, Yirmiya R (2008) Brain interleukin-1 mediates chronic stress-induced depression in mice via adrenocortical activation and hippocampal neurogenesis suppression. Mol Psychiatry 13:717-728. CrossRef Medline

Hariri AR, Gorka A, Hyde LW, Kimak M, Halder I, Ducci F, Ferrell RE, Goldman D, Manuck SB (2009) Divergent effects of genetic variation in endocannabinoid signaling on human threat- and reward-related brain function. Biol Psychiatry 66:9-16. CrossRef Medline

Hill MN, Gorzalka BB (2009) Impairments in endocannabinoid signaling and depressive illness. JAMA 301:1165-1166. CrossRef Medline

Howlett AC, Breivogel CS, Childers SR, Deadwyler SA, Hampson RE, Porrino LJ (2004) Cannabinoid physiology and pharmacology: 30 years of progress. Neuropharmacology 47:345-358. CrossRef Medline

Kathuria S, Gaetani S, Fegley D, Valiño F, Duranti A, Tontini A, Mor M, Tarzia G, La Rana G, Calignano A, Giustino A, Tattoli M, Palmery M, Cuomo V, Piomelli D (2003) Modulation of anxiety through blockade of anandamide hydrolysis. Nat Med 9:76-81. CrossRef Medline

Kim KS, Lee KW, Baek IS, Lim CM, Krishnan V, Lee JK, Nestler EJ, Han PL (2008) Adenylyl cyclase-5 activity in the nucleus accumbens regulates anxiety-related behavior. J Neurochem 107:105-115. CrossRef Medline

Koo JW, Duman RS (2009) Interleukin-1 receptor-null mutant mice show decreased anxiety-like behavior and enhanced fear memory. Neurosci Lett 456:39-43. CrossRef Medline

Layé S, Parnet P, Goujon E, Dantzer R (1994) Peripheral administration of lipopolysaccharide induces the expression of cytokine transcripts in the brain and pituitary of mice. Brain Res Mol Brain Res 27:157-162. Medline

Lister RG (1987) The use of a plus-maze to measure anxiety in the mouse. Psychopharmacology 92:180-185. Medline

Long-Smith CM, Collins L, Toulouse A, Sullivan AM, Nolan YM (2010) Interleukin- $1 \beta$ contributes to dopaminergic neuronal death induced by lipopolysaccharide-stimulated rat glia in vitro. J Neuroimmunol 226:20-26. CrossRef Medline

Maccarrone M, Rossi S, Bari M, De Chiara V, Fezza F, Musella A, Gasperi V, Prosperetti C, Bernardi G, Finazzi-Agrò A, Cravatt BF, Centonze D (2008) Anandamide inhibits metabolism and physiological actions of 2-arachidonoylglycerol in the striatum. Nat Neurosci 11:152-159. CrossRef Medline

Maccarrone M, De Chiara V, Gasperi V, Viscomi MT, Rossi S, Oddi S, Molinari M, Musella A, Finazzi-Agrò A, Centonze D (2009) Lipid rafts regulate 2-arachidonoylglycerol metabolism and physiological activity in the striatum. J Neurochem 109:371-381. CrossRef Medline

Maccarrone M, Bernardi G, Finazzi-Agrò AF, Centonze D (2011) Cannabinoid receptor signaling in neurodegenerative diseases: a potential role for membrane fluidity disturbante. Br J Pharmacol 163:1379-1390. CrossRef Medline

Manna SS, Umathe SN (2011) Transient receptor potential vanilloid 1 channels modulate the anxiolytic effect of diazepam. Brain Res 1425: 75-82. CrossRef Medline

Marsch R, Foeller E, Rammes G, Bunck M, Kössl M, Holsboer F, Zieglgänsberger W, Landgraf R, Lutz B, Wotjak CT (2007) Reduced anxiety, conditioned fear, and hippocampal long-term potentiation in transient receptor potential vanilloid type 1 receptor-deficient mice. J Neurosci 27:832-839. CrossRef Medline

Mathew SJ, Ho S (2006) Etiology and neurobiology of social anxiety disorder. J Clin Psychiatry 67 [Suppl 12]:9-13.

Micale V, Cristino L, Tamburella A, Petrosino S, Leggio GM, Drago F, Di Marzo V (2009) Anxiolytic effects in mice of a dual blocker of fatty acid amide hydrolase and transient receptor potential vanilloid type-1 channels. Neuropsychopharmacology 34:593-606. CrossRef Medline

Miller AH, Maletic V, Raison CL (2009) Inflammation and its discontents: the role of cytokines in the pathophysiology of major depression. Biol Psychiatry 65:732-741. CrossRef Medline

Moreau M, Lestage J, Verrier D, Mormede C, Kelley KW, Dantzer R, Castanon N (2005) Bacille Calmette-Guérin inoculation induces chronic activation of peripheral and brain indoleamine 2,3-dioxygenase in mice. J Infect Dis 192:537-544. CrossRef Medline

Musella A, De Chiara V, Rossi S, Prosperetti C, Bernardi G, Maccarrone M, Centonze D (2009) TRPV1 channels facilitate glutamate transmission in the striatum. Mol Cell Neurosci 40:89-97. CrossRef Medline

Musella A, De Chiara V, Rossi S, Cavasinni F, Castelli M, Cantarella C, Mataluni G, Bernardi G, Centonze D (2010) Transient receptor potential vanilloid 1 channels control acetylcholine/2-arachidonoylglicerol coupling in the striatum. Neuroscience 167:864-871. CrossRef Medline

Nestler EJ, Carlezon WA Jr (2006) The mesolimbic dopamine reward circuit in depression. Biol Psychiatry 59:1151-1159. CrossRef Medline

Norman GJ, Karelina K, Zhang N, Walton JC, Morris JS, Devries AC (2010) Stress and IL-1beta contribute to the development of depressive-like behavior following peripheral nerve injury. Mol Psychiatry 15:404-414. CrossRef Medline

Oprica M, Zhu S, Goiny M, Pham TM, Mohammed AH, Winblad B, Bartfai T, Schultzberg M (2005) Transgenic overexpression of interleukin-1 receptor antagonist in the CNS influences behaviour, serum corticosterone and brain monoamines. Brain Behav Immun 19:223-234. CrossRef Medline

Pace TW, Hu F, Miller AH (2007) Cytokine-effects on glucocorticoid receptor function: relevance to glucocorticoid resistance and the pathophysiology and treatment of major depression. Brain Behav Immun 21:9-19. CrossRef Medline

Patel S, Hillard CJ (2006) Pharmacological evaluation of cannabinoid receptor ligands in a mouse model of anxiety: further evidence for an anxiolytic role for endogenous cannabinoid signalling. J Pharmacol Exp Ther 318:304-311. CrossRef Medline

Picazo-Juárez G, Romero-Suárez S, Nieto-Posadas A, Llorente I, JaraOseguera A, Briggs M, McIntosh TJ, Simon SA, Ladrón-de-Guevara E, Islas LD, Rosenbaum T (2011) Identification of a binding motif in the S5 helix that confers cholesterol sensitivity to the TRPV1 ion channel. J Biol Chem 286:24966-24976. CrossRef Medline

Rao JS, Harry GJ, Rapoport SI, Kim HW (2010) Increased excitotoxicity and neuroinflammatory markers in postmortem frontal cortex from bipolar disorder patients. Mol Psychiatry 15:384-392. CrossRef Medline

Reichenberg A, Yirmiya R, Schuld A, Kraus T, Haack M, Morag A, Pollmächer T (2001) Cytokine-associated emotional and cognitive disturbances in humans. Arch Gen Psychiatry 58:445-452. CrossRef Medline

Reiman EM, Fusselman MJ, Fox PT, Raichle ME (1989) Neuroanatomical correlates of anticipatory anxiety. Science 243:1071-1074. CrossRef Medline

Rogan MT, Leon KS, Perez DL, Kandel ER (2005) Distinct neural signatures for safety and danger in the amygdala and striatum of the mouse. Neuron 46:309-320. CrossRef Medline

Rosenbaum DM, Cherezov V, Hanson MA, Rasmussen SG, Thian FS, Kobilka TS, Choi HJ, Yao XJ, Weis WI, Stevens RC, Kobilka BK (2007) GPCR engineering yields high-resolution structural insights into beta2adrenergic receptor function. Science 318:1266-1273. CrossRef Medline

Rossi S, De Chiara V, Musella A, Kusayanagi H, Mataluni G, Bernardi G, Usiello A, Centonze D (2008) Chronic psychoemotional stress impairs cannabinoid-receptor-mediated control of GABA transmission in the striatum. J Neurosci 28:7284-7292. CrossRef Medline

Rossi S, De Chiara V, Musella A, Sacchetti L, Cantarella C, Castelli M, Cavasinni F, Motta C, Studer V, Bernardi G, Cravatt BF, Maccarrone M, Usiello A, Centonze D (2010) Preservation of striatal cannabinoid CB1 receptor function correlates with the anti anxiety effects of fatty acid amide hydrolase inhibition. Mol Pharmacol 78:260-268. CrossRef Medline

Snyder SH (2011) Serotonin, cytokines, p11, and depression. Proc Nat Acad Sci U S A 108:8923-8924. CrossRef Medline

Starowicz K, Nigam S, Di Marzo V (2007) Biochemistry and pharmacology of endovanilloids. Pharmacol Ther 114:13-33. CrossRef Medline

Starowicz K, Cristino L, Di Marzo V (2008) TRPV1 receptors in the central nervous system: potential for previously unforeseen therapeutic applications. Curr Pharm Des 14:42-54. CrossRef Medline

Steiner H, Van Waes V, Marinelli M (2010) Fluoxetine potentiates methylphenidate-induced gene regulation in addiction-related brain regions: concerns for use of cognitive enhancers? Biol Psychiatry 67:592594. CrossRef Medline

Suzuki S, Kiyosue K, Hazama S, Ogura A, Kashihara M, Hara T, Koshimizu H, Kojima M (2007) Brain-derived neurotrophic factor regu- 
lates cholesterol metabolism for synapse development. J Neurosci 27: 6417-6427. CrossRef Medline

Topol EJ, Bousser MG, Fox KA, Creager MA, Despres JP, Easton JD, Hamm CW, Montalescot G, Steg PG, Pearson TA, Cohen E, Gaudin C, Job B, Murphy JH, Bhatt DL, Bhatt DL (2010) Rimonabant for prevention of cardiovascular events CRESCENDO: a randomised, multicenter, placebo-controlled trial. Lancet 376:517-523. CrossRef Medline

Tyring S, Gottlieb A, Papp K, Gordon K, Leonardi C, Wang A, Lalla D, Woolley M, Jahreis A, Zitnik R, Cella D, Krishnan R (2006) Etanercept and clinical outcomes, fatigue, and depression in psoriasis: double-blind placebo-controlled randomised phase III trial. Lancet 367:29-35. CrossRef Medline

van Dam AM, Brouns M, Louisse S, Berkenbosch F (1992) Appearance of interleukin-1 in macrophages and in ramified microglia in the brain of endotoxin-treated rats: a pathway for the induction of nonspecific symptoms of sickness? Brain Res 588:291-296. CrossRef Medline

Yoo HK, Kim MJ, Kim SJ, Sung YH, Sim ME, Lee YS, Song SY, Kee BS, Lyoo IK (2005) Putaminal gray matter volume decrease in panic disorder: an opti- mized voxel-based morphometry study. Eur J Neurosci 22:2089-2094. CrossRef Medline

Zhang G, Li Q, Wang L, Chen Y, Wang L, Zhang W (2011) Interleukin-1 $\beta$ enhances the intracellular accumulation of cholesterol by upregulating the expression of low-density lipoprotein receptor and 3-hydroxy-3methylglutaryl coenzyme A reductase in podocytes. Mol Cell Biochem 346:197-204. CrossRef Medline

Zhang HT, Huang Y, Masood A, Stolinski LR, Li Y, Zhang L, Dlaboga D, Jin SL, Conti M, O'Donnell JM (2008) Anxiogenic-like behavioral phenotype of mice deficient in phosphodiesterase 4B PDE4B. Neuropsychopharmacology 33:1611-1623. CrossRef Medline

Zhu CB, Blakely RD, Hewlett WA (2006) The proinflammatory cytokines interleukin-1beta and tumor necrosis factor-alpha activate serotonin transporters. Neuropsychopharmacology 31:2121-2131. CrossRef Medline

Zorrilla EP, Luborsky L, McKay JR, Rosenthal R, Houldin A, Tax A, McCorkle R, Seligman DA, Schmidt K (2001) The relationship of depression and stressors to immunological assays: a meta-analytic review. Brain Behav Immun 15:199-226. CrossRef Medline 